\title{
Reforming the Power of the Purse \\ A Look at the Fiscal and Budgetary ReLationship between the District of Columbia and the U.S. Congress
}

\section{By Noah Wepman}

Abstract: The fiscal and budgetary relationship between the U.S. Congress and the District of Columbia is inconsistent with the typical federal governance system. In its current position, the District s fiscal and budgetary authority is somewhere between that of a central city vis-à-vis its state capital and that of an Executive-level agency, like the Department of Commerce. The District is restricted in how it can raise revenue and formulate an annual budget, resulting in an often fragile fiscal environment. This article looks at the history of the current arrangement and suggests ways to reform the relationship between these two distinct government entities.

Washington, D.C., is an anomaly in the federal-statelocal construct of American governance. As such, there is an ongoing struggle between the federal government and local leaders over the power of the purse and the right to set and control local priorities.

The federal district is neither an autonomous territory nor part of a state. Instead, the U.S. Congress has become a de-facto state legislature for the District, placing limitations on the process of budgetary decisions and the choices made by the city. In this role, the Congress has taken a more active role in the governance of the District than other state legislatures have taken in their cities. In addition to having final say over the District's budget, Congress also places limits on methods the District can use to raise revenue. Together, these restrictions greatly diminish the District's fiscal autonomy.

Difficulties striking the right balance between congressional oversight and local control are the cause of strained relations between the federal government and the citizens of Washington, D.C. In fact, a recent Washington Post editorial noted that ensuring the city's long-run fiscal viability is the most pressing problem facing District leaders (2001).

Federalism fosters conflict between any two governments that share jurisdiction over a particular geographic territory (Rowat, 1973). Federalism in the United States is characterized by dual sovereignty; states act independently of the national government. In addition, Dillon's Rule posits that local governments are creatures of the states and therefore possess only those powers allocated by state governments. The federal district of Washington falls somewhere between these two levels of control, a status that has caused major strife between the Congress and District officials.

This article examines the roots of the fiscal relationship between the Congress and the District, including the District's fiscal crisis and recovery of the 1990 s, and compares it to governance models in other states and cities. Finally, a summation of proposals is presented, followed by the introduction of a new model that balances self-governance with limited congressional oversight.

\section{An Historical Perspective}

The Founding Fathers created a federal district under the control of the national government so that the nation's capital would not be influenced by the interests of a particular state.

The relationship between the District of Columbia and the federal government has been tenuous since the establishment of the federal district by the Constitution. The appropriate level of fiscal dependence or independence from Congress has never been clear. From 1800 to 1871 , District citizens appealed to Congress for reimbursement of costs related to operating

Noah Wepman earned a Masters of Public Administration degree with a concentration in budget and public finance from The George Washington University, . He received a bachelor s of Arts from Colby College and has lived in the District of Columbia intermittently for 12 years. Currently, he works as a budget analyst for the Washington, D.C., Public School System. 
and maintaining a city that developed on a scale beyond the means of the average municipality. A fixed system of determining the amount of federal support for the District did not exist until 1879 , though federal payments to support local government operations were made in twelve of the years between 1790 and 1822 and every year between 1823 and 1876 .

Congress reorganized the District's government in 1878 and settled on an agreement to pay 50 percent of the municipal costs (Richards, 2001). This arrangement continued until 1921, when Congress' payment was reduced to 40 percent of municipal costs. The lump sum payment method, negotiated in 1925, existed until the 1990s (Financing the Nation's Capital, 1990).

In 1973 Congress passed a home rule charter (PL $93-$ 198), granting the citizens of Washington, D.C., limited local control. The law gave the new city council and mayor taxing authority over all local matters with some notable exceptions, including nonresident income and property of the United States. Compared to the taxing authorities in other cities, this was a substantial restriction. (With the exceptions of Washington, D.C., and Baltimore, Maryland, every city in America that imposes an income tax on its residents also imposes a nonresident income tax.) These taxing limitations accounted for an estimated 1.7 billion dollars in lost revenue in FY1994 (O'Cleireacain, 1997).

Included in the home rule act was the Diggs Compromise $^{2}$, which, among other provisions, granted Congress line-item control over the city's budget. Congress continues to exercise this authority as part of its annual budget process. The annual District budget, therefore, is not finalized until Congress and the president approve the District's appropriations bill.

As part of the home rule charter, the federal government transferred responsibility for the District's finances to the newly elected local government. The District, however, began home rule with poor financial management structures in place. In 1975 an independent accounting study prepared for the Senate found that the financial information published by the District was not reliable, that the District's most recent annual report contained inaccurate and misleading figures, and that internal financial reporting was not reliable, timely, or consistent (Arthur Anderson). In fact, there was no actual audit of the District's books until 1980.

\section{Financial Crisis and Recovery}

By the 1980s the finances of the District were in a precarious state. The crisis stemmed from a combination of poor financial management by the District, including accumulated operating deficits and unfunded pension liabilities left over from the period preceding home rule, a shrinking tax base as middleclass families left the city for the suburbs, a stagnating economy, and an increased demand for services (Financing the Nations Capital, 1990). Many services traditionally funded by states, such as Medicaid, Welfare, mental health, foster care, higher education, and services commonly shared by state and local governments, such as public education, debt service, and adult corrections, were left to the District to fund from a limited tax base (Dearborn and Meyers, 1996).

The Congress, acting as the District's "state legislature," did provide some assistance through annual lump-sum payments. These payments, however, were not consistent and did not always match the District's needs. This was especially true after the implementation of home rule. In FY1976, when home rule began, the federal appropriation was 24 percent of the District's operating expenditures. By FY1990 it amounted to only 14 percent of the District's budget (Financing the Nation s Capital, 1990) and in FY1995, federal payments rebounded to 25 percent of the District's discretionary revenues (O'Cleireacain, 1991).

In 1989 a 90 million dollar deficit was projected for FY1990; the deficit was expected to balloon to 700 million dollars by FY1996 (Financing the Nation s Capital, 1997). That same year D.C. Mayor Marion Barry appointed the Commission on Budget and Financial Priorities, headed by Alice Rivlin, to develop a fiscal strategy for the District of Columbia for the fiscal years 1992 through 1996. The Rivlin Commission created a blueprint for addressing the city's most pressing fiscal problems. Rivlin also offered to become the District's chief financial officer in a bid to help the city avert financial collapse. The report and Rivlin's offer, however, were ignored by then-Mayor Sharon Pratt Dixon.

In 1995, after failing to balance its budget, the District did not have sufficient funds to pay its bills and was shut out of capital markets (O'Cleireacain, 1997). Congress then created the District of Columbia Financial Responsibility and Management Assistance 
Authority (the Control Board) (PL 104-8), which reported directly to the White House and Congress and took over the financial management for the city and many other responsibilities given to the District under home rule. Under the new law, the Control Board would become dormant after the city balanced its budget for four consecutive years and was able to re-enter the bond market.

In 1997 President Bill Clinton proposed, and Congress passed, the National Capital Revitalization Act, which was designed to revitalize Washington, D.C., and improve the possibility of a return to normalized home rule. The Revitalization Act transferred many of the District's state-level responsibilities to the federal government. Most notably, the federal government took over funding for prison renovation, construction and operations, the court system, and infrastructure improvements and increased the federal share of the District's Medicaid payments. Also, the federal government resumed responsibility for the city's existing underfunded pension plans for police officers, firefighters, teachers, and judges, allowing the city to establish new plans for current employees. In exchange, the annual lump-sum payments to the District were reduced. The act, however, made no alterations to the District's ability to raise revenue,

The District reached fiscal solvency by the late 1990s as a result of actions taken by the Control Board, changes brought about by the Revitalization Act, help from a booming economy, and the installation of sound financial management and controls. On October 1, 2001, the Control Board effectively ended its tenure after the District balanced its budget for the fourth consecutive year and was allowed to re-enter the bond market (the criterion established by the law that created the Control Board). Fiscal year 2002 began with the District in control of its fiscal management for the first time since 1995 and a projected 464 million dollar surplus (District of Columbia Proposed Operating Budget, FY2002).

The fiscal crisis experienced by the District was not unique. On three recent occasions, state authorities have stepped in to bring major cities back from the brink of bankruptcy. In New York City, the state created two agencies-the Municipal Assistance Corporation (MAC) and the New York State Emergency Control Board-to deal with the city's financial crisis of 1975. The state of Ohio created the Financial Planning and Supervision Commission to work with Cleveland over the period of a year in 1980 to return it to fiscal solvency after the city defaulted on $\mathbf{1 5 . 5}$ million dollar in short-term notes in 1978 (Gillette, 1997). The state of Pennsylvania created the Pennsylvania Intergovernmental Cooperation Authority in 1991 to review Philadelphia's budgets and to borrow money on behalf of the city. When these cities regained fiscal solvency, these oversight boards were either dissolved or their powers were greatly reduced.

\section{The District and Congress Today}

Although the District has fully recovered from the fiscal crisis of the 1990s and the Control Board is dormant, the District continues to have a body actively overseeing its finances-the U.S. Congress. In fact, the Congress, in its role as a state legislature, is more stringent than any other state legislature. For all intents and purposes, the Congress treats Washington, D.C., as a federal agency whose budget is subject to comprehensive congressional oversight.

The District must submit its budget to Congress (after it has been approved by the mayor and City Council) for review and approval as part of the federal budget process. Indeed, the District has its own congressional appropriations subcommittee. Although federal funds constitute approximately one-fourth of the District's budget (District of Columbia Proposed Budget, FY2002) and these funds are primarily entitlements that all states receive, Congress essentially re-appropriates the entire District budget back to the city as if it were all federal money.

Formulation of the District's budget typically begins some 12 to 15 months before the fiscal year begins. The mayor develops the budget and submits a proposal to the City Council. Once the budget is approved by the Council and signed by the mayor it is sent to the Congress for approval and then to the president for his 
REFORMING THE POWER OF THE PURSE

signature. The goal is for completion by October 1 , the beginning of the fiscal year (District of Columbia City Council, 2001). In recent years Congress has failed to approve the District's appropriation until well into the beginning of the fiscal year. ${ }^{3}$

When delays occur, Congress routinely passes a continuing resolution that allows the District to spend at or near the current level of services of the prior year. Such inconsistencies limit the District's ability to plan adequately, to implement new programs, to hire new staff, and to do other things that are included in the new budget that were not part of the previous year's budget (After the Control Board, 2001).

This arrangement particularly affects school operations. Fiscal Year 2002 was the first year that Congress granted the D.C. public schools the budget authority to spend a portion (10 percent) of its fiscal year 2002 budget early in anticipation of the upcoming school year (D.C. Proposed Budget, FY2002). In the past, the D.C. Public School System had to wait until a budget was passed (even under ideal conditions, new budgets do not take effect until October $1^{\text {st }}$ ) before it could spend money above the previous year's level.

Congress also intervenes in the city's affairs through legislative riders attached to the District's budget. Although legislating in an appropriations bill is technically prohibited, Congress often ignores this rule. As part of past appropriations bills, Congress has superseded D.C. Council-enacted procedures for the establishment of public charter schools, voided the Legalization of Marijuana For Medical Treatment Initiative of 1998, prohibited the use of local funds to provide abortions to residents who request them, limited the scope of the District's Human Rights Act, and legislated civil fines for possession of cigarettes by minors (Proposed Operating Budget for Washington, DC FY2002).

In FY2002 the House of Representatives deleted 33 of 67 riders from the District's budget. The District of Columbia Appropriations Subcommittee struck down city-approved proposals to spend locally raised tax dollars to increase police salaries in order to commit 10 million dollars toward drug abuse programs for juveniles and adults (including Welfare recipients) and to make $\$ 296,000$ available to the Child Facility Review Committee, the panel charged with investigating the deaths of foster children (Washington Post, 2001).
Other state legislatures do not restrict municipal budgeting in any such manner. For example, the state of Maryland, in its FY2002 budget, allocated money for local and state aid programs to all municipalities with only categorical limitations on spending, such as education, libraries, transportation, etc. (Maryland Proposed Budget, FY2002). The same can be said for Massachusetts and its state aid programs (Massachusetts Proposed Budget, FY2002). Neither state provided aid grants with strings attached nor do they require state approval for municipal budgets. The spending and budget limitations placed on the District, especially once the city reached financial stability, are a point of contention between city residents and the federal district.

\section{Unique Challenges to Governing}

As the nation's seat of government, the District faces issues that are unique to the national capital city. The District is home to many people and organizations that enjoy tax-exempt status. Many embassies and headquarters of non-profit organizations-property that is exempted from property tax by federal law-are located in the District. Combined, real and personal property tax exemptions are estimated to cost the District approximately 540 million dollars annually at FY2001 tax rates (D.C. Proposed Budget, FY2002).

Also, many individuals living in the District are exempt from local income taxes. These include elected officers of the federal government, presidential appointees subject to confirmation by the Senate, justices of the United States Supreme Court not domiciled in the District, and employees on legislative staffs who are bona fide residents of the state of their elected officer (D.C. Proposed Budget, FY2002).

As the capital of the United States, the District benefits from a strong tourism, convention, and conference industry. These sectors contribute a substantial amount to the District's economy. For example, hotel sales tax raised 858 million dollars in FY2000 (D.C. Proposed Budget, FY2002). In the same year, the room occupancy excise tax in Boston brought in less than 24 million dollars (City of Boston Operating Budget, FY2002). Therefore, events that reduce travel, such as the terrorist attacks of September 11, 2001, deeply affect the District's economy.

These circumstances make the relationship between the District and the federal government different from 
that of any other state and its major city. But even more disturbing is the fact that the District has a very large oversight board (the entire Congress) that is not directly accountable to the people it oversees. In other states and cities, voters can vote politicians out of office. This is not the case in the District. It is unlikely that Rep. Joe Knollenberg (R-Michigan), chair of the Appropriations Subcommittee for the District of Columbia, would be voted out of office for attaching too many riders to the District's appropriations bill.

\section{Proposals for Reform}

Numerous modifications have been proposed to improve the fiscal and budgetary relationship between the District and its "state legislature." Some pertain to the District's taxing authority and available tax base; others propose various degrees of separation between the District and the federal government. ${ }^{4}$ Following is a summary of popular reform proposals.

\section{Increased "State" Aid Payments}

State aid grants, awarded in addition to providing certain services, constitute a crucial component of cities' general revenue. Congress, however, does not award aid to the District in parity with aid given to similar sized cities from their state legislatures.

In FY1995, before the Revitalization Act, the federal government provided the District with a lump-sum payment of 660 million dollars and required it to provide state-level services (O'Cleireacain, 1997). The same year, Massachusetts provided Boston with approximately 429 million dollars and Maryland provided Baltimore with more than 650 million dollars in state aid. These aid payments translated into per capita spending of $\$ 768$ per person in Boston, $\$ 946$ in Baltimore and $\$ 1,197$ in Washington, D.C.

However, in FY2000, after the implementation of the Revitalization Act, the District received 24 million dollars (DC Budget, FY2002), Massachusetts provided Boston 480 million dollars in state aid (City of Boston Budget, FY2002) and Baltimore collected 135 million dollars from Maryland (City of Baltimore Budget, FY2002). Calculated on a per capita basis, this amounts to $\$ 814$ in Boston, $\$ 207$ in Baltimore and $\$ 42$ in D.C. ${ }^{5}$ Increased aid payments that are aligned with cities of similar size would allow the District greater flexibility in its budget.

\section{Tax Reform}

A number of studies recommend some form of tax restructuring and reform for the District. The Rivlin Commission in 1989 recommended that Congress give the District the authority to tax nonresidents' income. This proposal was reiterated in 1997 by Carol O'Cleireacain in The Orphaned Capital, in 1998 by the District's 'Tax Revision Commission, ${ }^{6}$ and in Mayor Anthony Williams' FY2002 Budget and Financial Plan: Building a City That Works for Everyone - Neighborhood by Neighborhood.

In addition, Congresswoman Eleanor Holmes Norton (D-District of Columbia) introduced the District of Columbia Nonresident Tax Credit Act (HR 4358) in May 2001 as part of a larger fiscal recovery bill, ${ }^{7}$ The bill proposed that a two percent local wage tax be imposed on nonresidents working in the District, the national average commuter tax rate. An offsetting credit would be claimed on the filer's federal income tax.

Other tax restructuring proposals include streamlining business taxes, cutting real property taxes, lowering personal income tax, increasing fees, and broadening the tax base.

\section{Budget Process Reform}

After the Control Board (2001), a report by the D.C. Appleseed Center, recommended that the District budget be separated from the federal budget. Because Congress has not always acted in a timely fashion to adopt the District's budget, the city often begins a fiscal year not knowing the size or details of its budget. While federal agencies endure such limitations whenever the federal budget enactment is delayed, no local political jurisdiction other than the District of Columbia is subject to such uncertainty.

The extended budget approval process-for both regular and supplemental appropriations-has an impact on the District's expenditures. Much can happen between the initial forecast of revenues and actual budget execution. During a budget year, the District cannot adjust expenditures upward or downward except by going through a lengthy supplemental appropriation 
process in Congress. As a consequence, the District faces more uncertainty about revenue and expenditures than other cities and states. Other taxing jurisdictions have mechanisms for adjusting to economic changes during a fiscal year. Maryland, for example, makes an initial revenue estimate six months before the start of a fiscal year, a revision three months later and a mid-course correction five months into the fiscal year so that expenditures can be changed if appropriate (D.C. Proposed Budget, FY2002).

Separating the two budget processes has support in Congress. Congresswoman Connie Morella (RMaryland), chairwoman of the House Oversight Committee on the District of Columbia, and Delegate Norton introduced The District of Columbia Fiscal Integrity Act of 2001 (HR 2995), which would give the District autonomy over its budget beginning in FY2003.

\section{PILOTs}

From the perspective of a city, property tax exemptions are the most significant lost source of revenue (O'Cleireacain, 1997). Even with 42 percent of its land tax exempt, the District receives 21 percent of its revenue from property taxes, making this the second largest revenue source behind income taxes in FY2002 (DC Proposed Budget, FY2002). Payments in lieu of taxes (PILOTs) are often discussed as a means to offset lost revenue due to the tax exempt status of the federal property in the District.

The federal government already uses several PILO'T programs to reimburse local governments. The broadest program was created by the Payment in Lieu of Taxes Act of 1976 (PL 94-565) to compensate local governments for losses to their tax bases due to the presence of certain categories of federally owned land, including lands in the National Park Service, National Wildlife Reserves, and lands administered by the Bureau of Land Management. The federal government is estimated to have made 200 million dollars in PILOT payments in FY2001 (Budget of the U.S., FY2002). In addition, 34 states have policies designed to reimburse municipalities for tax-exempt property (Fong and Kuenzi, 1994). For example, Massachusetts is expected to make a PILOT payment of 21 million dollars to Boston in FY2002 (City of Boston Budget, FY2002).

\section{Recommendations for Change}

Most state residents do not elect federal representatives to come to Washington to be "mayors." And, undoubtedly, representatives and senators do not relish this role. Congressional actions during the last 30 years, including the Home Rule Act in 1973, the passage of the District Voting Rights constitutional amendment in 1978 (the amendment, however, was not ratified by the states), and the Revitalization Act in 1997, demonstrate an increasing recognition of the state-level role Congress chooses to take with the District.

The same Members, however, feel that D.C. warrants a certain level of oversight based on its fiscal history. The first locally elected government of the District sat for only three years (1871-1874) before a financial scandal motivated Congress to disband the government and replace it with an appointed Board of Commissioners. More than a century later, another fiscal crisis forced Congress to create a Control Board and independent Chief Financial Officer to directly manage financial functions (Proposed Operating Budget for Washington, D.C., FY2002).

The following proposals, some of which should be considered mutually exclusive, balance greater flexibility for the District in its budget and finances while ensuring that congressional oversight is maintained.

Enactment of a nonresident tax. Nonresidents earn two-thirds of all income in the District yet pay no District income tax (District of Columbia Tax Rates and Tax Burdens, 2001). The inability to tax this income -a right held and exercised in other jurisdictionstranslates into a huge loss of revenue for the city. O'Cleireacain estimated that nonresident tax would generate about 880 million dollars annually for the District $^{8}$ in FY1998, thus placing the obligation to support services in the nation's capital on those nonresidents who benefit from them ( $O^{\prime}$ Cleireacain, 1997).

The reverse is also true-District residents who work outside the District enjoy benefits in the surrounding area without paying for them. In fact, 15 states and the District of Columbia have reciprocity agreements that allow residents to pay income tax only to their state of residence (Commerce Clearing House, 1996). This eases tax administration and does not represent a loss in state revenue when its residents' income earned in other states approximates and offsets nonresidents' local 
earnings. For the District, however, which has reciprocity agreements with Maryland and Virginia, the income earned by nonresidents exceeded residents' earnings outside the city by 19.9 billion dollars in FY1994 (O'Cleireacain, 1997).

PILOT system for property owned by the federal government. Forty-two percent of property in the District is tax exempt. Sixty-five percent of this property belongs to the federal government. (O'Cleireacain estimated that the revenue impact would have been approximately 609 million dollars in FY 1998 if federally owned land were taxed at $\$ 2.15$ per $\$ 100$ of assessed value, which was the FY1998 rate.) Payments could also be calculated on a formulaic basis, but would not necessarily equal the amount the federal government would otherwise owe if it were not tax exempt. The reason for this is set forth by the U.S. Supreme Court in McCulloch v. Maryland (1819), which accepted the argument that state and local governments could erode the power of the federal government through taxation (O'Cleireacain, 1997). In other words, if left to their own devices, states and localities could limit the federal government's presence in their jurisdictions by levying unreasonable taxes on federal property.

The Advisory Board Commission on Intergovernmental Affairs made a compelling case for PILOTs in Payments in Lieu of Taxes on Federal Real Property (1959).

By acquiring real property, the government has assumed a responsibility borne by private taxable property owners. Thus, it should make payments in lieu of taxes on much the same basis as owners of private property pay real estate taxes. Failure to treat the federal government in this manner violates the horizontal equity canon of public finance, that "equals be treated equally," with the index of equality here being the value of real property that is owned (81).

Continued federal payments for "state-level" services. Congress will not soon give up its role as a state legislature for the District of Columbia. As such, it should continue for fund traditional state-level services, which include various education, health, and highway programs.

Removal of the District's annual budget from the federal budget process. Seventy-five percent of the funds appropriated in the District's FY2001 budget were raised locally (District of Columbia Proposed Budget, FY2002). The District budget should not be held captive by a federal budget process that is seldom completed on schedule. These delays make it very difficult for the District to budget properly for a year's worth of expenditures. Because the District in recent years has established the foundation for sound fiscal management, Congress need not rely on the annual appropriations process to ensure that the District's finances will be well managed (After the Control Board, 2001).

Implementation of performance measures for the District. During the fiscal crisis of the 1990s, Congress set specific requirements that the city had to meet in order to regain control of its finances. A model that combines oversight with local control and flexibility can be derived from this experience and extended to combine current federal reform efforts.

The Government Performance and Results Act (GPRA) of 1993 (PL 103-62) requires federal agencies to submit several reports to Congress. The five-year strategic plans include a mission statement, goals and objectives, relationship of annual performance goals to strategic objectives, and program evaluations. Annual performance plans specify measurable goals, set performance indicators, and provide a basis of comparing actual and planned performance. Finally, agencies must prepare annual performance reports that review whether goals for the previous year were achieved (Schick, 2000).

Similar reports could be required of the District to ensure that goals are being achieved. Like federal agencies, the District would create reports for the entire city, not just for individual municipal agencies, and submit them to the District oversight committees in Congress. Unlike GPRA, Congress would not use the reports as a basis for appropriations. Rather, the reports would serve as indicators of both the District's financial solvency and use of proper planning and resource management techniques. Measures might include maintaining certain types of budgetary reserve funds, implementation of a performance-based budgeting process, and economic growth targets.

In addition, the District has begun a pilot program to use performance-based budgeting. In FY2003 seven agencies will present their entire budget as a programmatic budget. The goal is to expand this type 
of budgeting to all agencies and eventually tie resource allocation to outcomes.

These requirements allow Congress to keep a watchful eye on the District while at the same time leaving long-term planning to the local government.

Congressional requirement of clean audits. Once the District's budget is no longer subject to congressional approval, committees with jurisdiction over the District of Columbia (the Appropriations Subcommittee and the District of Columbia Oversight Subcommittee) should require annual unqualified (clean) audit opinions of the District's finances. If two consecutive clean audits are not issued, the District of Columbia Appropriations Subcommittee would regain line-item control of the District's budget.

\section{Re-activation of the Control}

Board if crisis looms. When the Control Board was suspended on September 30,2001, it became dormant, not extinct. Provisions of the law creating the Control Board allow for re-activation if any of seven events occur. Among these events are the default of any loans, bonds, notes or other form of borrowing, failure of the city government to meet its payroll for any pay period, or the failure to make required pension and benefits payments. $^{9}$ This policy is an effective deterrent for District budgeters and should not be discontinued.

\section{Conclusion}

Historically, Congress and the District of Columbia have not agreed on District budgetary and fiscal matters. Although Congress has relinquished some control in recent years, it continues to keep a firm grasp on the District's purse strings. Members of Congress defend this approach by pointing to the District's recent fiscal crisis. It is important to note, however, that many of these same Members (or recent Members) were charged with watching over the District before and during the crisis.

This article has proposed a new governance structure designed to balance local control with some oversight built on a trust between the Congress and the District. Congress must trust that it can put better financial management tools in place and give the District the tools it needs to be financially secure throughout different periods of the business cycle. This is especially true in the current economic climate.

An April 2000 study by the Greater Washington Research Center concluded that there was no room for either a tax reduction or a discretionary increase in program expenditures unless dollar for dollar reductions in spending were made in other parts of the budget (Dearborn, 2000). The outlook for FY2002 is also bleak. Testifying before the City Council on October 19, 2001, Natwar Gandhi, the District's chief financial officer, warned of a 245 million dollar shortfall in the District's budget due to declining tax revenue (partly as a result of the events of September $11^{\text {th }}$ ) and unforeseen health and education costs (Washington Post, 2001).

At the same time, the District must recognize that some congressional oversight is not necessarily a bad thing. Just as other cities have state governments to watch over them and lend a hand when necessary, the District should welcome congressional assistance. The District is a "company town," and as such should recognize the many benefits it enjoys as the seat of government for the United States. The District benefits financially from the presence of the federal government and associated industries (lobbying firms, legal offices, tourism, etc.). These industries provide substantial economic benefits for the region; the city often receives extra attention from federal agencies interested in providing added services in their own back yards. In addition, the federal government maintains 85 percent of Washington's parkland and rivers and operates 24 museums, a zoo, an arboretum, and a performing arts center. Federal law enforcement officers patrol 28 percent of the city (Powell, 1997).

In the end, both levels of government can greatly benefit from the presence of the other. This particular governance structure, unique to the American governmental construct, should be viewed as an opportunity for collaboration rather than as a struggle for control. 


\section{Notes}

${ }^{1}$ Dillon's Rule is named for Judge John F. Dillon, who wrote in 1868 on the topic of state and local relations, providing a framework for interaction between the two entities still in existence today. Dillon wrote that the power of municipalities was limited to those powers "expressly granted, necessarily or fairly implied or absolutely indispensable" to the local governments allocated by state governments.

${ }^{2}$ Named for Representative Charles C. Diggs, Jr. of Michigan. This compromise was essential to garner the support of Representative William Natcher (D-KY), the chairman of the District of Columbia Appropriations Subcommittee. His support carried not only many members of the Appropriations Committee, but also a large number of Southern congressmen and was essential to enacting home rule for the district.

${ }^{3}$ The FY1996 budget was approved seven months after the beginning of the fiscal year. The FY1998 budget was delayed 1.5 months, FY1999 was three weeks late, FY2000 was 1.5 months late, FY2001 was 1.5 months late and the FY2002 budget was 81 days late.

${ }^{4}$ There are also ongoing efforts for D.C. statehood. This proposal, while not without merits, is outside the scope of this paper.

${ }^{5}$ Per capita calculations were conducted using U.S. Census data.

${ }^{6}$ The mayor and City Council created the Tax Revision Commission in 1996 to recommend comprehensive changes in the District taxes and other revenues.

${ }^{7}$ HR 4358 was referred to the House Ways and Means Committee, and no further action has been taken

${ }^{8}$ This is calculated by taxing nonresident income at Virginia income tax rates, the lowest in the region.

${ }^{9}$ For a full list see "News Release," District of Columbia Financial Responsibility and Management Assistance Authority, February 14, 2001, for a complete list of these events.

\section{References}

Advisory Commission on Intergovernmental Relations. (1959). Payments in lieu of yaxes on federal real property.

D.C. Appleseed Center. After the Control Board: The Chief Financial Officer and Financial Management of the District of Columbia. (2001, June).

Chan, Sewell. (2001, October 1). After 6 years of recovery, still no cure. The Washington Post, p. B1, B4.
Chan, Sewell. (2001, October 1). Wide-scale woes slow big-picture solutions. The Washington Post, p. B4.

City of Baltimore Operating Budget, FY2002.

City of Boston Operating Budget, FY2002.

Commerce Clearing House. (1996), State Tax Guide.

Commission on Budget and Financial Priorities of the District of Columbia. (1990). Financing the nation's capital: the report of the commission on budget and financial priorities of the District of Columbia.

Commonwealth of Massachusetts. Governor's Proposed State Operating Budget, FY2002.

D.C.'s Awesome Challenge. (2001, November 10). The Washington Post, p. A26.

D.C.'s Trouble in the House. (2001, September 25). The Washington Post, p. A22.

Dearborn, Phillip. (2000, April). Potential problems in the District's 2001 budget. Greater Washington Research Center.

Dearborn, Phillip \& Meyers, Carol. (1996, August). The necessity and costs of District of Columbia services. Greater Washington Research Center.

District of Columbia. (2001, August). Tax rates and tax burdens in the District of Columbia - A nationwide comparison.

District of Columbia. Mayor's proposed FY2002 budget and financial plan: Building a city that works for everyone - neighborhood by neighborhood.

District of Columbia City Council website. www.dccouncil.washington.dc.us/

District of Columbia Tax Revision Commission. (1998). Tax revision commission summary report.

Fong, Christina \& Kuenzi, Jeff. (1994). Reimbursing municipalities for the presence of state-owned properties. Boston: University of Massachusetts Press.

Gillette, Howard. (1997). Washington's fiscal crisis: An introduction. City Renewal Project.

Harris, Charles Wesley. (1995). Congress and the governance of the nations capital. Washington, D.C.: Georgetown University Press. 


\section{REFORMING THE POWER OF THE PURSE}

HR 2995 (107 $^{\text {th }}$ Congress). District of Columbia Fiscal Integrity Act of 2001. Sponsor: Representative Constance Morella. Introduced October 2, 2001.

HR 4358 (106 $^{\text {th }}$ Congress). Omnibus District of Columbia Tax Incentive Recovery Act of 2000. Sponsor: Representative Eleanor Holmes Norton. Introduced May 2, 2000.

Hsu, Spencer. (2001, October 19). D.C. fiscal chief sees shortfall of $\$ 245$ million. The Washington Post, p. B1, B4.

King, Colbert. (2001, September 29). Democracy for the District, too. The Washington Post, p. A27.

Norton wants budget provisions restored. (2001, September 11). The Washington Post, p. B3.

O'Cleireacain, Carol. (1997). The orphaned capital: Adopting the right revenues for the District of Columbia. Washington, D.C.: Brookings Institution Press.

O'Cleireacain, Carol \& Rivlin, Alice. (2001, June). Envisioning a future Washington. The Brookings Institution.

Office of Management and Budget. Proposed budget of the United States government, fiscal year 2002.

PL 93-198 District of Columbia Self-Government and Government Reorganization Act (1973, December 24).

PL 94-565 Payments in Lieu of Taxes Act (1976, October 10).

PL 103-62 The Government Performance and Results Act (1993, August 3).

PL 104-8 District of Columbia Financial Responsibility and Management Assistance Authority Act (1995, March 17).

PL 105-33 Balanced Budget Act of 1997 (1997, August 5).

Powell, Michael. (1997, July 20). Federal presence in D.C. regarded as both an asset and an albatross. The Washington Post, p. A19.

Report on the Accounting and Financial Practices of the District of Columbia Government. (1976, June). Arthur Anderson \& Co. prepared for the U.S. Senate Committee on the District of Columbia.
Richards, Mark David. (2001, September 7). Citizens' guide to the congressional appropriations process for Washington, D.C." D.C. Watch.

Richards, Mark David. (2001, June). Touring hidden Washington, DC: Living in the shadows of congress. D.C. Watch.

Rowat, Donald (Ed.). (1973). The government of federal capitals. Toronto: University of Toronto Press.

Second-guessing the District. (2001, September 11). The Washington Post, p. A26.

Schick, Allen. (2000). The federal budget: Politics, policy, and process. Washington, D.C.: The Brookings Institution.

State of Maryland. Governor's Proposed Operating Budget, FY2002.

Taskforce on the District of Columbia Governance. (1997, April). Final Report and Recommendations. National Association to Restore Pride in America's Capital.

United States Census Bureau, www.census.gov

Well done. (2001, October 3). The Washington Post, p. A30.

White House News Release. The President's National Capital Revitalization and Self Government Improvement Plan. (1997, January 14). 